\title{
Albumin to alkaline phosphatase ratio: does it predict survival in grade 1 and grade 2 neuroendocrine tumors?
}

Yusuf Acikgoz ( $\nabla$ yacikgoz86@gmail.com)

TC Saglik Bakanligi Ankara Numune Egitim ve Arastirma Hastanesi https://orcid.org/0000-0002-03607938

Öznur Bal

TC Saglik Bakanligi Ankara Numune Egitim ve Arastirma Hastanesi

Mutlu Doğan

Dr Abdurrahman Yurtaslan Onkoloji Egitim ve Arastirma Hastanesi

Research article

Keywords: Albumin, ALP, neuroendocrine tumor, prognosis

Posted Date: December 3rd, 2019

DOI: https://doi.org/10.21203/rs.2.17508/v2

License: (c) (1) This work is licensed under a Creative Commons Attribution 4.0 International License. Read Full License

Version of Record: A version of this preprint was published at Pancreas on January 1st, 2021. See the published version at https://doi.org/10.1097/MPA.0000000000001720. 
The authors have withdrawn the journal submission associated with this preprint and requested that the preprint also be withdrawn. 